\title{
Teacher Perception toward Offline Final Examination on Covid-19 Pandemic
}

\author{
Rasyid Anwar Dalimunthe', Syaripuddin Daulay², Lusinta Rehna Ginting3, \\ Mely Nadia4
}

DOI: $10.35445 /$ alishlah.v13i1. 519

\begin{tabular}{l} 
Article Info \\
\hline Keywords: \\
Evaluation \\
Semester Examination \\
Implementation \\
Offline System
\end{tabular}

Kata kunci:

Evaluasi

Pelaksanaan Ujian

Semester

Sistem Luring

\begin{abstract}
The purpose of this study was to determine the implementation of the semester exams with an offline system. To get more accurate information about teachers' perceptions of the quality of student answers in the semester exams and student compliance with the rules of returning the questions promptly. The research method used is quantitative research methods with descriptive research design. The sample used in this study was 49 teachers who taught various subjects listed in the 2013 revised SMK level curriculum. While the data collection tools used were observation, questionnaires, interviews, literature study, then explained through tables and presented or tabulated by the teacher's answers using formulas. The results showed that the teacher's perception of students' answers in the offline system semester exams was poor or $63.26 \%$. Meanwhile, students' compliance with the rules of returning the questions and answers showed that they were on time or $48.97 \%$. So the researchers argue that the implementation of the semester exams with the offline system needs to be improved or look for other ways to improve the quality of student answers. And student compliance in returning questions and answers can be maintained and further enhanced for students who are still in the category of not being on time and not on time.
\end{abstract}

\begin{abstract}
Abstrak
Tujuan penelitian ini adalah untuk mengetahui pelaksanaan ujian semester dengan sistem luring. Untuk mendapatkan informasi yang lebih akurat tentang persepsi guru dengan kualitas jawaban siswa dalam ujian semester dan kepatuhan siswa terhadap aturan pengembalikan soal-soal yang dengan tepat waktu. Metode penelitian yang digunakan adalah metode penelitian kuantitatif dengan desain penelitian deskriptif. Sampel yang digunakan dalam penelitian ini adalah 49 guru yang mengajar dengan berbagai mata pelajaran sebagaimana tercantum dalam kurikulum 2013 revisi jenjang SMK. Sedangkan alat pengumpulan data yang digunakan adalah observasi, angket, wawancara, studi pustaka, kemudian dijelaskan melalui tabel dan disajikan atau ditabulasi jawaban guru menggunakan rumus. Hasil penelitian menunjukkan persepsi guru dengan kualitas jawaban siswa dalam ujian semester sistem luring menunjukkan kategori kurang baik atau 63,26\%. Sedangkan kepatuhan siswa terhadap aturan mengembalikan soal dan jawaban menunjukkan tepat waktu
\end{abstract}

\footnotetext{
${ }^{1}$ STAI Serdang Lubuk Pakam, Lubuk Pakam, Indonesia

Email: rad577rad@gmail.com

${ }^{2}$ Universitas Islam Negeri Sumatera Utara, Medan, Indonesia

Email: syarifudindaulay999@gmail.com

${ }^{3}$ Universitas Islam Negeri Sumatera Utara, Medan, Indonesia

Email: uchi1704@gmail.com

${ }^{4}$ Universitas Islam Negeri Sumatera Utara, Medan, Indonesia

Email: mely_nadiakareem@yahoo.com
} 
atau 48,97\%. Maka peneliti berpendapat untuk pelaksanaan ujian semester dengan sistem luring perlu diperbaiki atau mencari cara lain yang tentunya dapat meningkatkan kualitas jawaban siswa. Dan kepatuhan siswa dalam pengembalian soal dan jawaban dapat dipertahankan dan lebih ditingkatkan kepada siswa yang masih masuk pada kategori kurang tepat waktu dan tidak tepat waktu.

\section{INTRODUCTION}

Evaluation of the quality of school education is carried out under the Regulation of the Minister of National Education Number 20 concerning Education Evaluation Standards issued on June 11, 2007. The regulation stipulates that education evaluation standards are national education standards related to mechanisms, procedures and tools for assessing student learning outcomes. In contrast, educational evaluation is collecting and processing information to determine student learning outcomes (Suryani, 2017).

An evaluation activity is usually carried out in every activity to determine the level of success achieved by each activity. The teacher's success is evaluated in delivering the material and how students can absorb the material. Information can be obtained through the evaluation tools used. The teacher's assessment is an effort to make decisions on the success of the teaching and learning process, the level of learning readiness, and the realization of course objectives. The goal is to get quality education outcomes in related schools (Istika \& Prajono, 2019).

Assessment can encourage students to be more active and sustainable in learning. Teachers can also be encouraged to improve the quality of the learning process further. Schools can be encouraged further to improve the facilities and quality of student learning. In this connection, the optimization of the evaluation system has two meanings, first is the evaluation system that provides the best information. The second is the benefit of evaluation. The main advantage of evaluation is to improve the quality of learning. Besides that, the quality of education will also increase. (Mahirah, 2017)

Learning assessment is the last activity aiming to determine the extent to which learning objectives have been achieved. In addition, assessment can help teachers measure and evaluate student learning progress. As a measuring tool, this test is expected to provide credible information. A good test must prove its rationality regarding its feasibility, validity, reliability, interpretability, usefulness and effectiveness, including difficulty and good discriminating skills (Febriani, 2016).

An essential factor in the learning process is the evaluation of learning outcomes. The purpose of evaluating learning outcomes is to measure student learning outcomes after completing a series of learning processes. Carry out this assessment activity to find out whether the learning program implemented was successful. Evaluation of learning outcomes also aims to provide feedback as a basis for decision-making to improve the learning process (Wibawa, 2019).

The implementation of the end-of-semester assessment (PAS) is essential because it reflects the quality of each student and knows the success of learning so far. Given the importance of the end-of-semester assessment (PAS), a quality set of questions is needed in its implementation to ensure the quality of the questions given to students. PAS is an activity that measures the ability of students at the end of the semester. PAS monitors student learning progress after learning to determine student learning outcomes after the learning process and improve learning in the following semester. The PAS scope includes all indicators that represent all basic abilities during the period. A good test should consist of well-written questions to measure students' expected abilities and skills against the learning objectives. Asking behavior as an assessment tool cannot be underestimated to improve quality. Teachers must ask knowledge questions. Teachers must also be motivated to excel and receive information to reduce the gap between expectations and reality when the educational community asks questions (Sopiah et al., 2019).

During the Covid-19 period, teachers were required to become educators but still had to go to school. It needs to continue learning to ensure education. Teachers' primary responsibility and 
function will continue to be carried out because teachers are expected to educate and learn so that teachers are required to be creative in learning (Oyedotun, 2020).

According to the KBBI, the term " offline system " stands for "outside the network", disconnected from the computer network. For example, they are studying through student handbooks or face-to-face meetings. This type of offline system activity considers TVRI as learning content. Students collect their work in documents because offline system activities do not use the internet and computer networks but use other media. The offline system learning system is a faceto-face learning system (Malyana, 2020).

Meanwhile, offline learning means this kind of learning is nothing more than ordinary learning that teachers often used before it existed. Covid 19 is indeed a pandemic, but there have been several changes, such as shorter study times and reduced material. Learning using the offline method refers to the learning carried out by the teacher and students face-to-face, but offline means that the teacher provides material to students in hard copy assignments and then carries it out of school outside of school (Pratama, 2020).

Some previous research on offline systems, namely Thityn Ayu Nengrum et al., showed advantages and disadvantages to the method, media, and learning process. In this case, neither the offline nor online learning process can guarantee the basic skills of the course, and this can be maximally achieved (Nengrum, 2021). In addition, the results of Rio Erwan Pratama et al.'s research show that there are several obstacles in the implementation process. However, to educate students, teachers can overcome these obstacles appropriately. Both online and offline learning systems are expected to enable teachers to develop their creativity in educating students to achieve learning success effectively or adequately. The information provided by this study shows that teachers actually prefer offline learning that can interact with students, and students also like offline learning through face-to-face learning (Pratama, 2020).

This study reveals the effectiveness of implementing semester exams with an offline system (students bring questions and answer them at home and then take them back to school). Meanwhile, studies have not focused on offline learning only. This study was conducted during the covid-19 pandemic at SMK Negeri 1 Pantai Labu. The activities at that school also moved from home and sometimes took turns at school. Learning is carried out online and offline. This is because there are students who do not have an Android cellphone, and there are also students who are entirely unable to provide these tools so that SMKN 1 Pantai Labu also implements an offline system.

This research aims to know the real needs and situation toward the final examination based on the teacher's perception. After conducting this research, it is hoped that the results obtained can be a consideration for teachers and principals to decide policies in learning activities at the next school

\section{METHODS}

The research was conducted at SMKN 1 Pantai Labu from November until December 2020, when the exam was carried out until the odd semester exam finished the offline system. This type of research used in this research is quantitative research. The quantitative research method is one type of research whose specifications are systematic, well-planned and structured from the research design. In contrast, the research design used in this research is descriptive research. Thus, descriptive research is research that descriptive research is intended to investigate the circumstances, conditions, or other things that have been mentioned, the results of which are presented in the form of a research report (Sugiyono, 2011).

The population in this study were all subject teachers included in the 2013 revised vocational curriculum structure, totaling 49 teachers for the 2020/2021 school year. Meanwhile, according to Suharsimi Arikunto, the research sample, if the subject is less than 100 people, all of them must be taken; if the issue is more significant or more than 100 people, then it should be taken $10-15 \%$ or $20-$ $25 \%$ or more (Arikunto, 2010). So the sample in the study was 49 teachers with various subject areas included in the 2013 revised vocational curriculum structure. 
The research instrument is related to this research problem. The research instrument uses the following data collection tools: 1) Researchers made direct observations at SMK Negeri 1 Pantai Labu. 2) Researchers spread several questions related to research problems to 49 teachers in the form of a questionnaire. 3) The researcher conducted a question and answer session with the teachers to determine the quality of student answers and the consistency of students in complying with the rules for returning questions and answers. 4) Conduct a study search related to research (Arikunto, 2010).

While the data analysis used by the researcher is describing through tables and presenting or tabulating the answers of the teachers using the following formula:

Information: $\quad \mathrm{P}=$ Percentage

$$
P=\frac{F}{N} \times 100 \%
$$

$\mathrm{F}=$ Frequency

$\mathrm{N}=$ Number of Samples

Meanwhile, data analysis is carried out after reading all the descriptions and correlating them with the critical theory to obtain an objective conclusion. In particular, it can be done with qualitative research analysis theory, which consists of 1) data reduction, 2) data presentation, 3) concluding. (Sugiyono, 2011).

\section{FINDINGS AND DISCUSSION}

\section{Teacher Perception toward the Offline Examination at Home}

After distributing questionnaires to all samples about teacher perceptions of the quality of student answers during the offline system semester exams, the following results were obtained:

Table 1. Teachers' Perceptions of the Quality of Student Answers

\begin{tabular}{cccc}
\hline \hline Number & Category & Respondents & Frequency\% \\
\hline 1 & Very good & 7 & $14,29 \%$ \\
2 & Good & 11 & $22,45 \%$ \\
3 & Less good & 31 & $63,26 \%$ \\
4 & Not Good & - & \\
& & 49 & $100 \%$ \\
\hline
\end{tabular}

The results obtained from filling out a questionnaire show that the teacher who chose an outstanding student's answers was seven people or $14.29 \%$. The teacher who decided that the students' answers were quality, either numbering 11 people or equal to $22.45 \%$, teachers who chose poor quality of student answers totaled 31 people or $63.26 \%$. In contrast, those who decided not good quality of student answers did not exist.

From the results of $63.26 \%$ or less good, the teacher's perception of the quality of student answers using the offline system. The researcher argues that implementing this offline system is necessary to re-examine. Implement this offline system during semester exams or look for other ways such as alternating online with supervision from teachers. Because considering the implementation of the semester exams is very important in selecting and knowing the ability of students to understand the lessons that the previous teachers have taught.

While the results of distributing questionnaires to teachers regarding student compliance in returning questions and answers according to school rules. Then it can be seen as follows: 
Table 2. Returns Questions and Answers

\begin{tabular}{ccccc}
\hline \hline Number & Category & Respondents & Frequency \% & Time Indicator \\
\hline 1 & Very On Time & 15 & $30,61 \%$ & $13.00-13-20$ \\
2 & On Time & 24 & $48,97 \%$ & $13-20-13.40$ \\
3 & Less On Time & 10 & $20,42 \%$ & $13.40-14.00$ \\
4 & Not On Time & - & & $14.00-$ dst \\
& & 49 & $100 \%$ & \\
& Amount & &
\end{tabular}

The questionnaire results distributed to the teachers of SMKN 1 Pantai Labu show that the students returning the questions and answers worked on time. The students who were very punctual in returning the questions and answers amounted to 15 people or $30.61 \%$. The students on time totaled 24 or $48.97 \%$. The students who were not on time were ten people or $20.24 \%$. The results showed that the students were on time in returning the questions and answers below to each student's house. It is an awareness that should be nurtured continuously until students graduate from school. And also part of the school's success in instilling the importance of using the best possible time in terms of any activity, including semester exams using the offline system.

The most problem happened on offline examination at home is cheating and procrastinating. Cheating has finally become an international concern. Cheating does not only happen to middle or high school students but also in college. Cheating is a classic problem in the Indonesian education system. Unfortunately, the teachers, schools and related parties did not take this problem seriously, so cheating has continued to this day. Cheating is not the right way to get high scores. Under this influence, society will become tolerant of cheating. It will impact the ambiguity of moral values in all aspects of life and social systems, even weakening the power of society because the importance of honesty and hard work are often ignored (Astuti, 2016).

The characteristics of cheating are alarming, often looking left and right, looking back, asking for answers from other friends (next door), making movements on specific body parts and using fraudulent papers. There are internal factors, namely panic at the beginning of the exam, fear of being incomplete and ashamed of other friends, fear of disappointing parents, and worrying about taking the exam. Then, external factors, namely the influence of friends who usually cheat, housemates who are not interested in specific subjects (mathematics), parents who have high expectations of high grades and the number of students who excel in class and requirements. Based on these findings, the $\mathrm{ABC}$ (cause, behavior, consequence) diagnostic method will be used to design a behavior change program to optimize measures to prevent students from cheating (Andiwatir \& Khakim, 2019).

Honesty is a significant and fundamental thing that students must have. However, in school, the reality is that there are still many students who cannot be honest. One of them is cheating on exams, including daily exams, midterm exams, semester exams/class promotion exams, even national exams (Prihantari, 2017). When the learning assessment was carried out, it was seen that this imitation had become an act of cheating or plagiarizing the friends' answers next to them and copying from the answers prepared previously. This kind of cheating can disturb the calm atmosphere during an exam. It can lead to anger and protests from students who answer questions honestly or supervise teachers to punish students who cheat (Masada \& Dachmiati, 2016).

The Indonesian education system uses material tests or learning assessments to show the progress and mastery of student knowledge. Society only sees learning achievement in the process of achieving high scores rather than in the learning process. Exams are considered a ranking tool that can cause students to fail, not a tool that shows the progress of the learning process. Failure to pass a test or score is considered a threat and an unpleasant stimulus for students. Students show various reactions in response to the pressure. Through traditional study materials, additional study time, and practice course questions can show positive reactions. However, this kind of reaction can also appear in adverse reactions, one of which is cheating (Nurmayasari \& Murusdi, 2015). 
Exams are a learning process to evaluate results, but in reality, students cheat to pass the exam dishonestly. One of the reasons students cheat is low self-efficacy. Low self-efficacy encourages students to cheat through cheating or cooperation (Hidayat, 2015). According to Ehrlich's explanation, cheating means "engaging in dishonest or unfair behavior to gain or gain an advantage". One of the factors that cause students to cheat is self-distrust. The impact of cheating can damage students' confidence in their abilities. The efforts that counselors can make are to provide group guidance and discuss cheating. Cheating is a type of fraud committed by someone while doing homework and exams at school, university or other places. It is also a form of fraud or dishonest behavior (Amelia, 2016).

Cheating is the behavior of students looking for answers in various ways, such as reading notes, reading books, reading friends' answers and looking for answers from internet media. The goal is to fill in questions or answer questions even though they have their solutions. Get is not necessarily true. Almost all students in the class have cheated or committed fraud. This is due to lack of confidence, habit, laziness, lack of preparation and peer influence. Two factors cause students to cheat, namely internal factors (self) and external factors. Efforts to reduce cheating can be made: always get used to studying before exams, and during the day, control children and always remind children to learn often and provide punishment and rewards for students who cheat and do not cheat (Surur et al., 2018).

Individuals basically like freedom, don't like being ordered, don't like to be responsible, don't want to cooperate, like selfish, want to work with high income, and often break laws, such as being late for work or procrastinating. The act of not using up time or delaying doing something is called procrastination (delay). People who procrastinate are called procrastinators. Those who have difficulty completing work within the specified time limit experience delays, excessive preparation, and inability to complete the task. Procrastination is a time-wasting behavior, and there is a tendency not to work when faced with a task immediately. Delays can be seen from various aspects. Procrastination can only be said to be delayed or tends to slow starting work. Procrastination can also be said to avoid assignments because of dissatisfaction with the task and fear of failure. Procrastination is also a personal trait or habit of responding to assignments (Sandra \& Djalali, 2013), (Hakim \& Yama, 2020).

The management time is essential on offline examination at home (Nurhidayati, 2016). It turns out that most students don't have a good schedule. Students will continue to carry out daily activities spontaneously. Lack of day-to-day time management will cause students to study more during exams. Time management is self-regulation to use time as efficiently as possible to achieve goals. Time management can guide the student learning process. Poor learning time management will cause students to use simple learning methods in their learning. It will affect student learning outcomes. Therefore, students are expected to improve their time management skills by paying attention to aspects that must be avoided and resolved (Sari, 2017). The best use of time can improve the quality and professionalism of students based on subject competence (Yuswardi et al., 2016).

\section{CONCLUSION}

Evaluating the implementation of semester exams with the offline system from the teacher's perception of student answers' quality can be less good. It is necessary to rethink the implementation of this offline-based exam or replace it with another system to understand student answers better. Meanwhile, student obedience to school rules, especially on exams, has gotten good results. It means that the school only needs to increase students' compliance who still underestimate the current time or rules. So, the implementation of semester exams with this offline system should not be extended or not applied continuously anymore because it will be inaccurate in assessing students. 


\section{REFERENCES}

Amelia, S. H. (2016). Perilaku Menyontek Dan Upaya Penanggulangannya. Indonesian Institute for Counseling, Education and Therapy (IICET), 4(3), 1-9. https://doi.org/10.29210/3003226000

Andiwatir, A., \& Khakim, A. (2019). Analisis Perilaku Menyontek dan Rancangan Perubahannya pada Siswa SMP (Analysis of Cheating Behavior and Change Design in Junior High School Students). Psikologi Ilmiah, 11(2), 88-97. https://doi.org/10.15294/intuisi.v11i2.17808

Arikunto, S. (2010). Penelitian Tindakan Kelas. Bumi Aksara.

Astuti, Y. (2016). Persepsi Mahasiswa Terhadap Perilaku Menyontek (Studi Kasus Program Studi Manajemen S1 FEB-UMB Jakarta). Jurnal Ilmu Ekonomi dan Sosial, 5(3), 354-362.

Febriani, I. M. (2016). Analisis Butir Soal Ujian Akhir Semester (Uas) Bahasa Jerman Kelas X Mia 6 Sma Negeri 1 Maospati Tahun Pelajaran 2015/2016. Laterne, 7(2), 1-12.

Hakim, A., \& Yama, F. D. (2020). Efektivitas Penerapan Ujian Tanpa Pengawasan Melalui Pendidikan Karakter Berbasis Hadist Di Sma Islam Athirah Boarding School Bone. Nazhruna: Jurnal Pendidikan Islam, 3(1), 100-120. https://doi.org/10.31538/nzh.v3i1.489

Hidayat, T. (2015). Hubungan Antara Self Efficacy Dengan Perilaku Menyontek Saat Ujian Pada Mahasiswa Universitas Esa Unggul. Jurnal Psikologi, 13(1), 1-5.

Istika, N., \& Prajono. (2019). Kualitas Tes Ulangan Akhir Semester Mata Pelajaran Matematika Kelas VII Semester Ii Smp Negeri 12 Kendari. Penelitian Pendididikan Matematika, 7(2), 127-140. https://doi.org/10.36709/jppm.v7i2.8274

Mahirah B. (2017). Evaluasi Belajar Peserta Didik (Siswa). Idaarah, 1(2), 257-267. https://doi.org/10.24252/idaarah.v1i2.4269

Malyana, A. (2020). Pelaksanaan Pembelajaran Daring Dan Luring Dengan Metode Bimbingan Berkelanjutan Pada Guru Sekolah Dasar Di Teluk Betung Utara Bandar Lampung. Pedagogia: Jurnal Ilmiah Pendidikan Dasar Indonesia, 2(1), 67-76. https://doi.org/10.52217/pedagogia.v2i1.640

Masada H.T, C., \& Dachmiati, S. (2016). Faktor Pemengaruh Perilaku Siswa Dan Mahasiswa Menyontek. Sosio-E-Kons, 8(3), 227-233. https://doi.org/10.30998/sosioekons.v8i3.1168

Nengrum, T. A. (2021). Kelebihan dan Kekurangan Pembelajaran Luring dan Daring dalam Pencapaian Kompetensi Dasar Kurikulum Bahasa Arab di Madrasah Ibtidaiyah 2 Kabupaten Gorontalo. Jurnal Pendidikan, 30(1), 1-12. https://doi.org/10.32585/jp.v30i1.1190

Nurhidayati, D.D. (2016). Peningkatan Pemahaman Manajemen Waktu Melalui Bimbingan Kelompok Dengan Teknik Problem Solving pada Siswa. Psikopedagogia, 5(1), 24-32. https://doi.org/10.12928/psikopedagogia.v5i1.4592

Nurmayasari, K., \& Murusdi, H. (2015). Hubungan Antara Berpikir Positif Dan Perilaku Menyontek Pada Siswa Kelas X SMK Koperasi Yogyakarta. Empathy, 3(1), 8-15.

Oyedotun. (2020). Research in Globalization Sudden change of pedagogy in education driven by Covid-19: Perspectives and evaluation from a developing country. Research in Globalization, 2(100029). https://doi.org/10.1016/j.resglo.2020.100029

Pratama, R. E. (2020). Pembelajaran Daring dan Luring pada Masa Pandemi Covid-19. Gagasan Pendidikan Indonesia, 1(2), 49-59. https://doi.org/10.30870/gpi.v1i2.9405

Prihantari, R. (2017). Menurunkan Kebiasaan Mencontek Melalui Metode Apa? Lantas, Bagaimana? Dan Sekarang Bagaimana? Dalam Bimbingan Kelompok Pada Peserta Didik Kelas VIII.1 SMP N 1 Citeureup. Insight: Jurnal Bimbingan dan Konseling, 6(1), 40-49. https://doi.org/10.21009/Insight.061.04

Sandra, K. I., \& Djalali, M. A. (2013). Manajemen Waktu, Efikasi-Diri Dan Prokrastinasi. Persona, Jurnal Psikologi Indonesia, 2(3), 217-222. https://doi.org/10.30996/persona.v2i3.140

Sari, M. I. (2017). Manajemen Waktu pada Mahasiswa: Studi Kualitatif pada Mahasiswa Kedokteran $\begin{array}{lllll}\text { Universitas Lampung. } & \text { JK } & \text { Unila, } & \text { 1(3), }\end{array}$ https://doi.org/10.23960/jk\%20unila.v1i3.1714

Sopiah, A., et.al. (2019). Kualitas Soal Penilaian Akhir Semester (PAS) Buatan Guru Mata Pelajaran Kimia Kelas X IPA SMA Negeri Di Kabupaten Seruyan Pada Semester Ganjil Tahun Ajaran 2018/2019. Jurnal Ilmiah Kanderang Tingang, 10(2), 110-126. https://doi.org/10.37304/jikt.v10i2.27

Sugiyono. (2011). Metode Penelitian Kuantitatif, Kualitatif dan R\&D. Alfabeta. 
Surur, A. M., et. al. (2018). Problematika Pembelajaran Siswa MTS Sunan Gunung Jati (Studi Kasus Latar Belakang Siswa Menghadapi Ujian). Factor M, 1(1), 13-32. https://doi.org/10.30762/f_m.v1i1.960

Suryani, Y. E. (2017). Pemetaan Kualitas Empirik Soal Ujian Akhir Semester Pada Mata Pelajaran Bahasa Indonesia Sma Di Kabupaten Klaten. Jurnal Penelitian dan Evaluasi Pendidikan, 21(2), 142-152. https://doi.org/10.21831/pep.v21i2.10725

Wibawa, E. A. (2019). Karakteristik Butir Soal Tes Ujian Akhir Semester Hukum Bisnis. Jurnal Pendidikan Akuntansi Indonesia, 17(1), 87-96. https://doi.org/10.21831/jpai.v17i1.26339

Yuswardi, et. al. (2016). Manajemen Waktu Mahasiswa Kurikulum Berbasis Kompetensi Fakultas Keperawatan Universitas Syiah Kuala. Idea Nursing Journal, 7(3), 66-72. https://doi.org/10.52199/inj.v7i3.6448 